\title{
Települési önkormányzatokat érintő bevételkiesések a járványhelyzetben
}

\section{Revenue losses of local governments during pandemia KOVÁCS SÁNDOR ZSOLT}

\begin{abstract}
KOVÁCS Sándor Zsolt: tudományos segédmunkatárs, Közgazdaság- és Regionális Tudományi Kutatóközpont, Regionális Kutatások Intézete; 7621 Pécs, Papnövelde u. 22.; kovacs.sandor@krtk.mta.hu; https://orcid.org/0000-0001-6612-6296
\end{abstract}

KULCSSZAVAK: helyi önkormányzat; költségvetési elvonás; koronavírus; területi elemzés

Sándor Zsolt KOVÁCS: junior research fellow, Institute for Regional Studies, Centre for Economic and Regional Studies; Papnövelde u. 22., H-7621 Pécs, Hungary; kovacs.sandor@krtk.mta.hu; https:// orcid.org/0000-0001-6612-6296

KEYWORDS: local government; budget deduction; coronavirus; territorial analysis

\section{Bevezető}

A jelenleg zajló koronavírus pandémia miatt elrendelt veszélyhelyzetben több olyan kormányzati intézkedés is született, mely kihatással van a települési önkormányzatokra. ${ }^{1}$ Tanulmányom az önkormányzatokra, és jogszabályi felhatalmazást kapott polgármesterekre hárított korlátozó, megelőző intézkedések (fertőtlenítés, veszélyeztetett lakosságcsoportokról gondoskodás, intézmények bezárása, ügyeleti rendjének kialakítása stb.) áttekintésétől eltekintve, arra fókuszál, hogy az egyes döntések milyen hatással vannak a helyi költségvetésekre, milyen mértékben érintik a településeket. ${ }^{2}$

2020. április 6-án jelent meg a jogszabály (92/2020. Korm. rendelet.), melynek értelmében a központi költségvetés módosítása szükséges, s elrendeli három új fejezet, védekezési alap, a Járvány Elleni Védekezési Alap, a Gazdaságvédelmi Alap és az Európai Unióból Érkező Járvány Elleni Támogatások Alapja létrehozását. A kormány döntése értelmében ezek az alapok közös teherviselés mellett kerülnek létrehozásra, így többek között a pártok támogatásának 50\%-át elvonták, különadót vezettek be a bankszektorban, átcsoportosításra kerülnek egyes kiskereskedelmi adók és jelentős elvonások érik a települési önkormányzatokat is. Jelen elemzés célja, ez utóbbi kérdéskör, az önkormányzati bevételcsökkenések, költségvetési elvonások vizsgálata. 


\section{Gépjárműadó}

A rendelkezés szerint a gépjárműadó eddig települési önkormányzatoknál maradó részének (40\%) elvonása mintegy 34 milliárd forintot jelent a létrehozandó alapok mintegy 2000 milliárd forintos költségvetéséből. Schmidt Jenő, a Települési Önkormányzatok Országos Szövetségének (TÖOSZ) elnöke úgy nyilatkozott, hogy az alapnak ez csak egy kis része, de a településeknél nagy problémákat okozhat (hvg.hu 2020).

A gépjárműadó nem tekinthető helyi adónak, megosztott adó, 60-40 százalékban osztozik rajta az állam és az önkormányzatok (1991. évi LXXXII. törvény). Azonban a kormányrendelettel létrehozott Járvány Elleni Védekezési Alapba kerül át a 2020. évi önkormányzati részesedés.

Érdemes megvizsgálni azt, hogy mit is jelent ez a kiesés az önkormányzatoknak. Nagy léptékben nézve, településkategóriákat vizsgálva látható, hogy a bevételi szerkezetben átlagosan nagyon kis tételről beszélhetünk (1. táblázat). Azonban nagy mind a bevételi volumen, mind azok bevételek közötti arányának statisztikai terjedelme, ezért vizsgálatunkat településsorosan folytatjuk.

1. táblázat: A gépjárműadó bevétel átlagos értéke és költségvetési aránya településméret kategóriák szerint, 2017

Average volume and rate of the motor vehicle tax in the local governments' budget by settlement size, 2017

\begin{tabular}{lrr}
\hline \multirow{2}{*}{ Településtípus } & $\begin{array}{c}\text { Átlagos gépjármüadó bevétel } \\
\text { E Ft }\end{array}$ & $\begin{array}{c}\text { Átlagos bevételi arány } \\
\%\end{array}$ \\
\hline Főváros, kerületek & 5714489,0 & 0,58 \\
Megyei jogú város & 274078,3 & 1,18 \\
Város & 30841,6 & 1,32 \\
Nagyközség & 10390,8 & 1,24 \\
Község & 2706,6 & 1,36 \\
\hline
\end{tabular}

Forrás: KSH Tájékoztatási adatbázis

Az 1. ábra mutatja, hogy 2017. évi adatok alapján valóban a települések nagyobb körében, 2.352 településen ez a bevételtípus nem éri el a 20 millió forintot. A városok, megyei jogú városok körében azonban jóval e feletti összeg, 37 település esetében pedig a 100 millió forintot is meghaladó gépjárműadó bevétel realizálódott. Egy község, a Pest megyei, a budapesti agglomerációban elhelyezkedő Csomád kiemelkedett településkategóriájából a 247 millió forintot is meghaladó gépjárműadó bevételével.

A mérték mellett a bevételi szerkezetben betöltött arány, fontosság is vizsgálandó. A 2. ábra mutatja, hogy az önkormányzati bevételek közül a gépjármüadó aránya a kistelepüléseken a legnagyobb, 5 százalék feletti arányt csak községek esetében találhatunk. A korábban említett Csomád község pedig az 
1. ábra: A gépjárműadó bevétel volumene településenként, 2017 (millió Ft) Volume of motor vehicle tax by settlements, 2017 (million HUF)

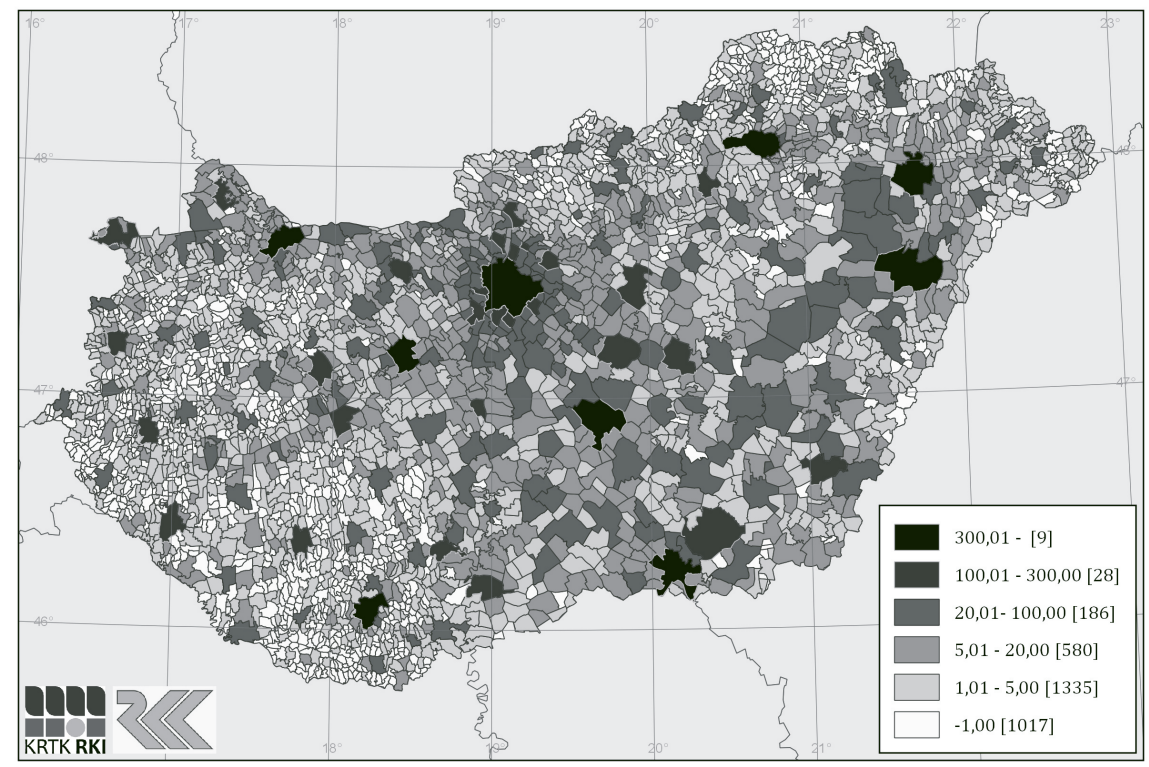

Forrás: KSH Tájékoztatási adatbázis adatai alapján a szerző szerkesztése

2. ábra: A gépjárműadó bevétel aránya a települések bevételei között, 2017 (\%) Rate of motor vehicle tax in the budget of local governments, 2017 (\%)

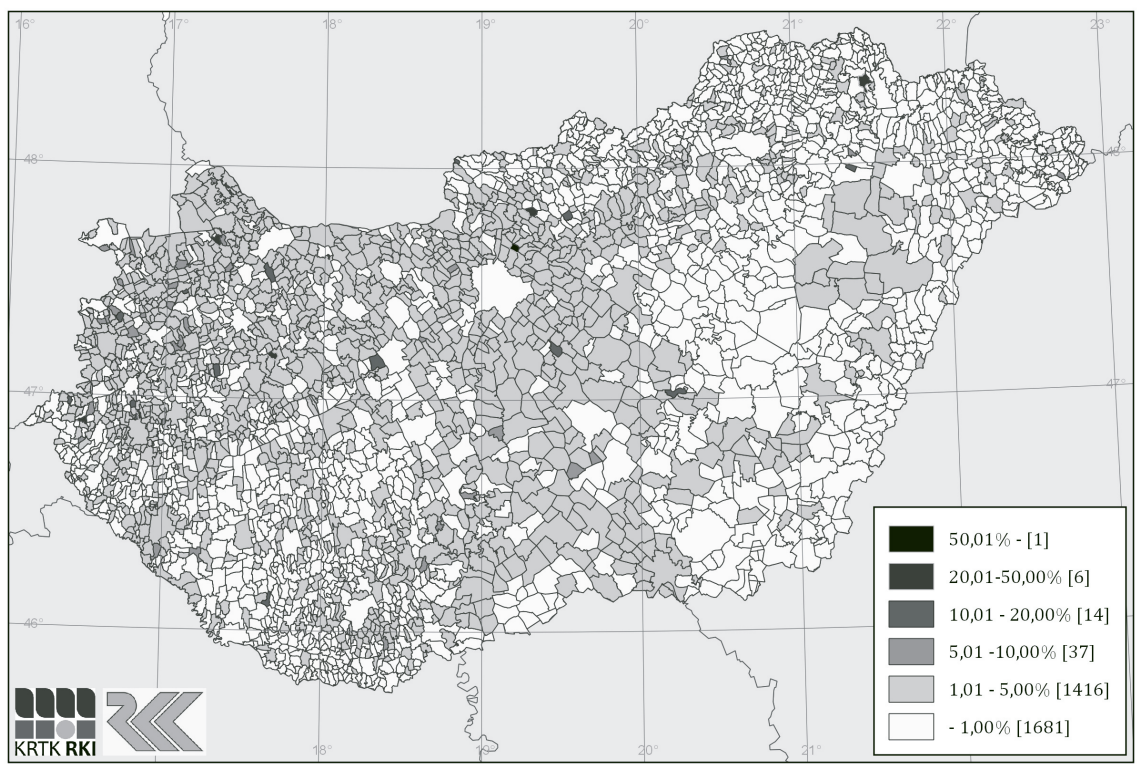

Forrás: KSH Tájékoztatási adatbázis adatai alapján a szerző szerkesztése 
egyetlen hazai település, amelynek bevételi szerkezetében a gépjárműadó több, mint 50 százalékot tesz ki. A probléma jelentőségét növeli, hogy míg a nagyobb településeken, ahol az arányaiban kisebb bevételkiesés pótlására több út is van (egyéb bevételi források átcsoportosítása, kiadások átgondolása), addig a kistelepülések esetében a visszapótlás esélye csekély, a kiadások többsége jelenleg is feszített, a bevételi források növelésére az esély elenyésző.

\section{Parkolási díjak}

Szintén a gépjárművekkel összefüggő, különösen a nagyobb önkormányzatokat érintő változás a 2020. április 6-tól érvényben levő, a közterületi parkolást az ország teljes területére kiterjedően ingyenessé tevő jogszabály (87/2020. Korm. rendelet). Ez mintegy 50 települést érint közvetlenül a G7 gazdasági portál kimutatása szerint. A fizető parkoló zónákat fenntartó önkormányzatoknál összességében a teljes bevétel 2,6 százalékát adták a parkolódíjak 2018-ban. A fövárosi kerületeknél azonban már 6,5 százalék ez az arány (g7.hu).

A rendelkezés célja, hogy a veszélyhelyzetben a lakosság könnyebben használhassa a tömegközlekedés helyett saját gépjárműveit a járvány terjedésének lassítása érdekében. A változás nem csak a bevételek csökkenésével jár, hanem negatív környezeti hatásokkal is járhat, ugyanis a veszélyhelyzet elrendelése óta Budapest esetében tapasztalható szénmonoxid és széndioxid kibocsátáscsökkenés (Varjú et al. 2020) újra emelkedhet az ingyenes parkolás okozta újbóli forgalomnövekedéssel (index.hu).

\section{Idegenforgalmi adó}

A települési költségvetések visszaesésének harmadik eleme az idegenforgalmi adó (IFA) felfüggesztése az év végéig (140/2020. Korm. rendelet). A 2017. évi, legfrissebb hozzáférhető adatok alapján ez a bevételkiesés 727 települést érint, ennyi önkormányzat tett szert IFA-bevételre a vizsgált évben. Ezeken a turisztikailag frekventált területeken ez a bevételi típus jelentős különbségeket mutat, mint azt a 3. ábra mutatja. Kiemelkedő értékek tapasztalhatók a főváros és a megyeszékhelyek, valamint olyan desztinációk esetében, mint a Balaton, Velencei és Fertő tavak környéke. A bevételi szerkezetben a legnagyobb arányú kiesést Zalakaros szenvedi el (21\%), de további 11 község és kisváros esetében is 10 százalék feletti kiesés prognosztizálható (Bikal, Bük, Demjén, Döbrönte, Hegykő, Hévíz, Lipót, Márokföld, Mátraszentimre, Paloznak, Parádsasvár).

Meg kell jegyeznünk, hogy ennek a kiesésnek a nagy része az adó felfüggesztése nélkül is jelentkezett volna, hiszen a tipikusan sok turistát és vendégéjszakát hozó Húsvét hétvége és valószínűsíthetően a Pünkösd időszaka is a vendégek elma- 
3. ábra: A települési önkormányzatok idegenforgalmi adó bevétele, 2017 (millió Ft) Tourism tax revenues of the local governments, 2017 (million HUF)

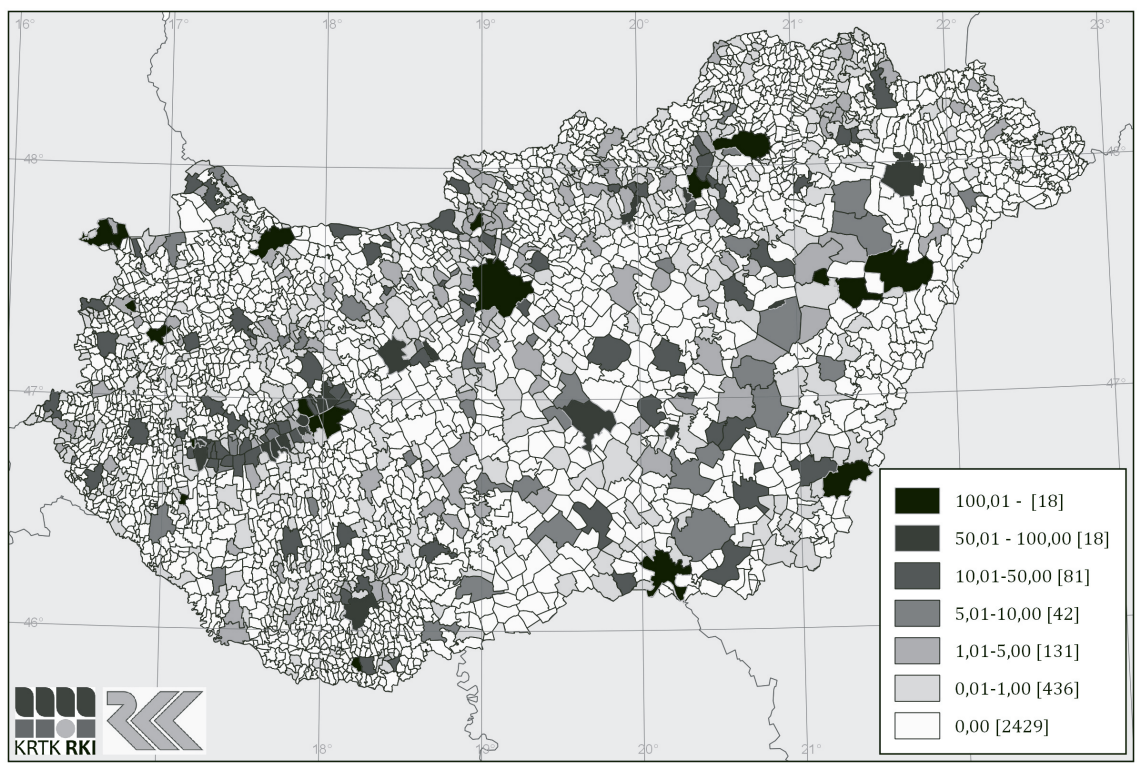

Forrás: KSH Tájékoztatási adatbázis adatai alapján a szerző szerkesztése

radását, jelentős visszaesését hozza, illetőleg a járvány tetőzésének és lecsengésének előrejelzései a nyári vendégfogadások drasztikus csökkenését vetítik előre.

\section{Iparüzési adó}

Még csak sejthető, hogy a kieső bevételek listája az iparűzési adó jelentős visszaesésével bővül, hiszen a krízishelyzetben sok vállalkozás részlegesen, vagy véglegesen felfüggesztette a tevékenységét, ami a jövő évben az adófizetési kötelezettséget, s így az önkormányzatok bevételét is csökkenteni fogja. Egyes önkormányzatok már erre az eshetőségre is készülnek.

E kérdéskörben biztosan változást hoz a veszélyhelyzettel összefüggésben hozott döntés, mely szerint kiemelt gazdasági övezetté nyilvánítható az a terület, amely legalább 100 milliárd forint teljes költségigényü, a megye területének jelentős részére kiható gazdasági jelentőségü, új beruházás vagy bővítés és munkahelyek tömeges elvesztésének prognosztizálható helyszíne (135/2020. Korm. rendelet). Az érintett területek esetében a szabályozási, adóztatási jogkörök a területileg illetékes megyei önkormányzathoz kerülnek, ezzel is csökkentve a helyi önkormányzat adóbevételeit (ado.hu). 


\section{Kevesebb pénzből kevesebb feladat?}

Egyelőre úgy tűnik, hogy nem. A korábban megszokott működés új, ad hoc változásokat kíván meg (fertőtlenítő eszközök és védőfelszerelés beszerzése, hivatali munka, intézmények átszervezése, lakossági ellátás, tájékoztatás), melyek kiadásnövekedést eredményeznek. Az önkormányzatok a költségvetéseik átcsoportosításával, dolgozóik intézmények közötti áthelyezésével, önkéntes munkával próbálják megoldani a veszélyeztetett korosztályok ellátásának segítését, a munkaerőpiacról kiesők támogatását és az egyéb hirtelen jött új feladatokat. Schmidt Jenő TÖOSZ elnök szerint viszont a felsorolt, helyi költségvetéseket csökkentő intézkedések után jogos elvárás lehet az önkormányzatok részéről, hogy az állam vállalja át a védekezéssel kapcsolatos feladatokat helyben is (hvg.hu 2020). Még egy esetleges állami kárpótlás sem tudja ellensúlyozni azonban a fentiekben elemzett bevételi források kiesését.

\section{Jegyzet}

1 A kézirat lezárásának időpontja: 2020. április 22.

2 A kézirat korábbi változata, mint a KRTK Regionális Kutatások Intézete koronavírussal összefüggő gyorselemzése, Önkormányzati bevételkiesések a járványhelyzetben címmel jelent meg, elérhetősége:: http://www.docs.rkk.hu/rkkweb/Onkorm_elemzes.pdf

\section{Irodalom}

1991. évi LXXXII. törvény a gépjárműadóról

87/2020. (IV. 5.) Korm. rendelet a várakozási díj megfizetésének a veszélyhelyzet során alkalmazandó eltérő szabályairól

92/2020. (IV. 6.) Korm. rendelet Magyarország 2020. évi központi költségvetésének a veszélyhelyzettel összefüggő eltérő szabályairól

135/2020. (IV. 17.) Korm. rendelet a veszélyhelyzettel összefüggésben a nemzetgazdaság stabilitásának érdekében szükséges intézkedésekről

140/2020. (IV. 21.) Korm. rendelet a Gazdaságvédelmi Akcióterv keretében a koronavírus-járvány gazdasági hatásainak mérséklése érdekében szükséges adózási könnyítésekről

https://ado.hu/ado/god-varosan-tesztelik-a-kulonleges-gazdasagi-ovezeteket/ (Letöltés: 2020. április 22.)

https://g7.hu/kozelet/20200407/mar-azelott-padlora-kerultek-az-onkormanyzatok-hogy-akormany-tovabb-utotte-volna-oket/ (Letöltés: 2020. április 14.)

https://hvg.hu/gazdasag/20200404_Jarvanyugyi_akcioterv_2700_telepulesen_nem_marad_egy_filler_sem_ha_elviszik_a_maradek_gepjarmuadot (Letöltés: 2020. április 14.)

https://index.hu/belfold/2020/04/09/megugrott_budapest_belvarosaban_a_forgalom/\# (Letöltés: 2020. április 14.)

Varjú V., Farkas O., Farkas J. Zs., Vér Cs. (2020): Az egyéni munkacélú személygépkocsi-közlekedés COVID-19 járvány következtében történő változásának néhány környezeti aspektusa Budapesten. Tér és Társadalom, 2., 183-189. https://doi.org/0.17649/TET.34.2.3263 